\title{
Bonding Monolithic Ultra-Translucent Zirconia Restorations to Endodontically Treated Teeth Systematic Review
}

\author{
Samir Koheil* and Eman Soliman \\ Professor of conservative dentistry and implant, Alexandria University, Egypt
}

*Corresponding author: Samir Koheil, professor of conservative dentistry and implant,

Alexandria University, Egypt.

\section{Objectives}

Challenges in bonding to endodontically treated teeth, where a different medicament were used on dentin and how it affects bond strength. when zirconia indirect restorations (onlays and crowns) were used where indirect restorations, is the choice especially if bonded to endodontically treated tooth with enough tooth structure.

Keywords: Endodontically treated teeth; Dental restoration; Zirconia monolithic; Sandblasting; Bond strength

\section{Formulate the Research Question}

Bonding monolithic zirconia to endodontically treated teeth

PICO: P-Problem: Bond strength endodontically treated teeth.

I-Intervention: Adhesion of monolithic ultra-translucent zirconia with sandblasting surface treatment.

C-Comparison: Zirconia adhesion to endodontically treated teeth and vital teeth.

O-Outcome: Bond strength.

\section{Introduction}

Restoration of root filled teeth could be challenging due to Structural difference between vital and non-vital teeth. Altered physical characteristics of the tooth structure remaining after endodontic therapy exhibit different changes, Calcified tissues of pulp less teeth have $9 \%$ less moisture content than in vital teeth [1]. The collagen too has fewer mature and more immature cross links. Changes in collagen cross linking and dehydration of the dentin result in $14 \%$ reduction in strength and toughness of endodontically treated molars. The combined loss of structural integrity, loss of moisture and loss of dentin toughness compromises, microstructural-composition changes, and changes in mechanical properties (bond strength, micro-hardness, nanohardness, modulus of elasticity and tensile strength $[2,3]$.

Treating dentin with 5\% sodium hypochlorite for two minutes produces dissolution of collagen and collagen-mineral bond, as well as changes in apatite crystallinity, resulting in a surface rich in apatite crystals [4]. Therefore, the substrate becomes more brittle, decreases its physical properties and produces a very weak bond and that the only fact of treating dentine with sodium hypochlorite and EDTA reduces surface micro-hardness [5-7]. Zirconia is resistant to aggressive chemical agents solving agents. Such chemical stability predicts superior long-term performance under the tough conditions of the oral environment [8].

Various chemical products were developed that is, a phosphate ester monomer, 10-methacryloyloxydecyl di-hydrogen phosphate (MDP) $[9,10]$. Nevertheless, the established bond strength was not sufficient for retaining adhesive zirconia restorations, as debonding under function was previously reported [11]. Various silica- coating methods were investigated and proved inefficient in increasing the retention of zirconia crowns [12,13]. Airborneparticle abrasion and roughening with diamond points, also failed to establish adequate mechanical retention to zirconia substrates $[14,15]$. In case of insufficient remaining tooth structure with more 
than one marginal ridge lost and weak remaining tooth structure therefore indirect restorations such as zirconia crowns inlays or onlays are the treatment of choice [16-21]. Chelators such as EDTA interact with the mineral content of dentin causes dentin erosion and softening as they mainly deplete calcium through complex formation and also affect non-collagenous proteins: proteoglycans, dentin phosphoproteins and sialoprofens [22].

Biological oxidant such as $\mathrm{NaOCl}$ and $\mathrm{H}_{2} \mathrm{O}_{2}$ cause the oxidation of some of the components of the dentin matrix, particularly collagen. They form protein-derived radicals that compete with the propagating vinyl- free radicals generated by the photo-activation of resin adhesives, resulting in premature chain termination and incomplete polymerization in addition; they liberate oxygen, which causes strong inhibition of polymerization in the adhesive system [23].

Zinc oxide and eugenol sealers and most temporary cements leave behind an oily debris $\mathrm{NaOCl}$ and $\mathrm{H}_{2} \mathrm{O}_{2}$ form an oxygen rich surface in dentin. The oxygen-rich layer left behind $\mathrm{NaOCl}$ can be reversed by a reducing agent like sodium ascorbate or ascorbic acid Gonulol et al. [24] reported that, treatment of access cavities and pulp chambers with $10 \%$ sodium ascorbate solution following endo treatment restores the sealing ability of resin with root dentin. $10 \%$ sodium ascorbate hydrogel might be as effective as $20 \%$ sodium ascorbate hydrogel in neutralizing the oxidizing effect and increasing the bond strength [25]. Chlorhexidine can significantly improve the resin-dentin bond stability anti-collagenolytic activity, because of its broad-spectrum metalloproteinase (MMP)-inhibitory effect [26-28]. Zamany et al [29], Abdullah et al [30] found that fusion of glass beads and plasma spraying, gave promising results.

\section{Material and Methods}

Two phases of the study selection were conducted

1. Abstracts and titles were selected.

2. Full tests of the selected titles were obtained and read to determine the final sample set through 2000 and 2019.
Also Nonrandomized longitudinal experimental clinical studies, longitudinal prospective studies, and longitudinal retrospective studies were reviewed. The choice of key words was intended to be broad to collect as much relevant data as possible both manually and electronically also, the references were thoroughly inspected for more possible candidates till May 20, 2019.

\section{Inclusion and Exclusion Criteria}

A search was performed in MEDLINE and PubMed for in vivo and vitro trials on zirconia restorations published between 2000 and 2019.

The main keywords used for the search; number of articles produced were:

1) “Zirconia and clinical"-329 articles

2) "Zirconia and fixed partial dentures"- 130 articles

3) “Zirconia and FPD"-23 articles

4) “Zirconia and implant abutments"-61 articles

5) "Zirconia and single crowns"-73 articles

In addition, a manual hand search was conducted through the literature to identify any possible clinical trials on Y-TZP, monolithic zirconia which may have not been listed on MEDLINE and PubMed. The articles found were read to identify ones which satisfied the following inclusion and exclusion criteria:

\section{Inclusion Criteria}

1. Human in vivo.

2. In-vitro studies.

3. Study has a set inclusion and exclusion criteria.

\section{Exclusion Criteria}

1. Case reports.

2. Animal studies.

3. Patients with bruxism or any para-functional habits.

\section{Result}

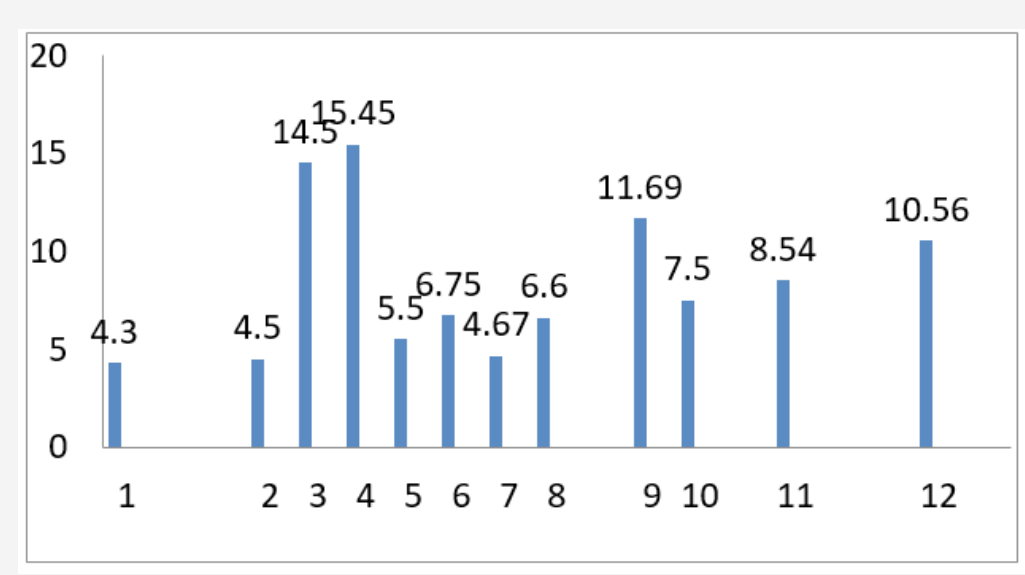

Figure 1: Showed that highest surface treatment was found in sandblasting techniques followed by airborne particles by silicone dioxide. 
The search yielded 12 articles and abstracts involving Y-TZP restorations which satisfied the inclusion criteria (Figure 1). From all retrieved papers the ones that described techniques developed to increase bond strength of $\mathrm{ZrO}_{2}$ to resin cement and their relationship with the material's composition were selected. Bond strength methods of selected papers were: Shear tests (19 papers), Microshear tests ( 3 papers), Tensile tests (5 papers), Microtensile tests (11 papers), and pull-out tests (01 paper). Just one paper employed both micro-tensile and shear bond strength methods, observing similar results (Table 1-3, Figure 2, Table 4, Figure 3-7).

Only zirconia-based ceramics BS measurements were listed in the table. Treatments were divided into: Chemical surface treatments, Mechanical surface treatments, and Alternative treatments.

Table 1: Retrieved papers from PubMed database search are, grouped in accordance with bond strength (BS) tests, type of ceramics, surface treatment method (STM), resin cements and results for BS improvement.

\begin{tabular}{|c|c|c|c|c|c|}
\hline $\begin{array}{c}\text { Name of Author } \\
\text { Year }\end{array}$ & $\begin{array}{l}\text { BS Method } \\
\text { and Value }\end{array}$ & $\begin{array}{l}\text { Type of } \\
\text { Ceramics }\end{array}$ & STM & Methods & Results \\
\hline $\begin{array}{c}\text { JR Piascik, EJ Swift, } \\
\text { JY Thompson, S } \\
\text { Grego, BR Stoner, } \\
2009 .\end{array}$ & MTBS & $\begin{array}{l}\text { Zir CAD and } \\
\text { Pro CAD }\end{array}$ & $\begin{array}{l}50 \mu \mathrm{mAl} 203 \\
\mathrm{AA}+2.6 \mathrm{~nm} \\
\text { Si } x 0 y ; \\
50 \mu \mathrm{mAl} 203 \\
\text { AA+23 nm } \\
\text { Si } x 0 y ; \text { CoJet }\end{array}$ & $\begin{array}{l}\text { Surface modifica- } \\
\text { tion for enhanced } \\
\text { silanation of zirconia } \\
\text { ceramic }\end{array}$ & $\begin{array}{l}\text { Analyzed using single-factor ANOVA }(\mathrm{p}<0.05) \text {. } \\
\text { Pre-treatment to deposit ultra-thin silica-like seed } \\
\text { layers can improve adhesion to zirconia using } \\
\text { traditional silanation and bonding techniques. This } \\
\text { technology could have clinical impact on how high } \\
\text { strength dental materials are used today. }\end{array}$ \\
\hline $\begin{array}{l}\text { RM Foxton, AN } \\
\text { Cavalcanti, M } \\
\text { Nakajima et al., } \\
2011 .\end{array}$ & Shear & Y-TZP & $\begin{array}{c}53 \mu \mathrm{mAl} 203 \mathrm{AA} ; \\
\text { YAG laser }\end{array}$ & $\begin{array}{l}\text { Durability of resin } \\
\text { cement bond to } \\
\text { aluminium oxide and } \\
\text { zirconia ceramics } \\
\text { after air abrasion and } \\
\text { laser treatment }\end{array}$ & $\begin{array}{l}\text { A significant statistical interaction between the } \\
\text { resin cements and surface treatments was detected } \\
\text { (p=0.004). In the surface-treated groups (air abrasion } \\
\text { and Er: YAG laser irradiation), the Bis-GMA-based } \\
\text { resin cement had higher bond strength than the MDP- } \\
\text { based cement. Both materials presented similar bond } \\
\text { strengths when no surface treatment was used. } \\
\text { With the groups cemented with the MDP-based mate- } \\
\text { rial, air abrasion resulted in significantly higher bond } \\
\text { strengths, while laser irradiation and the absence of } \\
\text { surface treatment presented similar results. }\end{array}$ \\
\hline $\begin{array}{l}\text { M Ozcan, C Cura, } \\
\text { LF Valandro, } 2011 .\end{array}$ & Shear & Y-TZP & $\begin{array}{l}\text { Silica coating; } \\
50 \mu \mathrm{m} \mathrm{Al} 203 \\
\text { AA; MPS and/or } \\
\text { 4-META silanes }\end{array}$ & $\begin{array}{l}\text { Early bond strength } \\
\text { of two resin cements } \\
\text { to Y-TZP ceramic } \\
\text { using MPS or MPS/4- } \\
\text { META silanes }\end{array}$ & $\begin{array}{l}\text { Results When the ceramic surfaces were silica } \\
\text { coated and Super Bond cement was used, mean bond } \\
\text { strength was not significantly However, when Panavia } \\
\text { F } 2.0 \text { cement was used, mean bond strength was } \\
\text { significantly higher. }\end{array}$ \\
\hline $\begin{array}{l}\text { RC De Oyague, F } \\
\text { Monticelli, M Tole- } \\
\text { dano, E Osorio,M } \\
\text { Ferrari, and R. } \\
\text { Osorio, } 2009 .\end{array}$ & MTBS & Y-TZP & $\begin{array}{c}125 \mu \mathrm{m} \mathrm{Al} 203 \\
\text { AA, TBC }\end{array}$ & $\begin{array}{l}\text { Influence of surface } \\
\text { treatments and resin } \\
\text { cement selection on } \\
\text { bonding to densely } \\
\text { sintered zirconiu- } \\
\text { moxide ceramic }\end{array}$ & $\begin{array}{l}\text { The highest shear bond strength values were ob- } \\
\text { served in Groups IV and V. The lowest shear bond } \\
\text { strength values were observed in Group I. Using } \\
\text { 10-methacryloyloxy-decyl dihydrogenphosphate } \\
\text { monomer-containing priming agents, e.g. Monoband } \\
\text { Plus and Z-PRIME Plus, combined with sandblasting } \\
\text { can be an effective method for resin bonding of zirco- } \\
\text { nia restorations. Discover the world's research }\end{array}$ \\
\hline $\begin{array}{l}\text { 39RC Oyague, F } \\
\text { Monticelli, M Tole- } \\
\text { dano, E Osorio, M } \\
\text { Ferrari, R Osorio, } \\
\quad 2009\end{array}$ & MTBS & Y-TZP & $\begin{array}{c}125 \mu \mathrm{mAl} 203 \\
\text { AA, Co Jet }\end{array}$ & $\begin{array}{l}\text { Effect of water } \\
\text { aging on microten- } \\
\text { sile bond strength } \\
\text { of dual-cured resin } \\
\text { cements to pre-treat- } \\
\text { ed sintered zirconi- } \\
\text { um-oxide ceramics }\end{array}$ & $\begin{array}{l}\text { RESULTS: Significant changes in zirconia surface } \\
\text { roughness occurred after sandblasting }(\mathrm{p}<0.001) \text {. } \\
\text { Bond strength of Clearfil cement to zirconia was sig- } \\
\text { nificantly higher than that of Rely x Unicem and Cal- } \\
\text { ibra, regardless of the surface treatment }(\mathrm{p}<0.001) \text {. } \\
\text { When using Calibra, premature failures occurred } \\
\text { in non-treated and silica coated zirconia surfaces. } \\
\text { SIGNIFICANCE: The phosphate monomer-containing } \\
\text { luting system (Clearfil Esthetic Cement) is recom- } \\
\text { mended to bond zirconia ceramics and surface treat- } \\
\text { ments are not necessary. }\end{array}$ \\
\hline $\begin{array}{c}\text { SS Atsu, MA } \\
\text { Kilicarslan, HC } \\
\text { Kucukesmen, PS } \\
\text { Aka } 2006\end{array}$ & Shear & Y-TZP & $\begin{array}{l}125 \mu \mathrm{mAl} 203 \\
\text { AA, Clearfil- } \\
\text { silanes, MDP } \\
\text { solution, and } \\
\quad \text { CoJet }\end{array}$ & $\begin{array}{l}\text { Effect of zirconi- } \\
\text { um-oxide ceramic } \\
\text { surface treatments on } \\
\text { the bond strength to } \\
\text { adhesive resin }\end{array}$ & \\
\hline $\begin{array}{c}\text { M Ozcan, H } \\
\text { Nijhuis, and LF } \\
\text { Valandro, Effect of } \\
\text { various, } 2008\end{array}$ & Shear & Y-TZP & $\begin{array}{c}50 \mu \mathrm{m} \mathrm{Al} 2 \mathrm{O} 3 \\
\text { AA; Korox; } \\
\text { Rocatec; flame } \\
\text { treatment }\end{array}$ & $\begin{array}{l}\text { surface condition- } \\
\text { ing methods on the } \\
\text { adhesion of dual-cure } \\
\text { resin cement with } \\
\text { MDP functional } \\
\text { monomer to zirconia } \\
\text { after thermal aging }\end{array}$ & $\begin{array}{c}\text { Data were statistically analyzed (one-way ANOVA, } \\
\alpha=0.05) \text {, whereby no significant differences were } \\
\text { found among the four groups }(8.43 \pm 1.3,8.98 \pm 3.6, \\
12.02 \pm 6.7 \text {, and } 8.23 \pm 3.8 \mathrm{MPa})(\mathrm{p}=0.1357) \text {. Therefore, } \\
\text { the performance of chairside conditioning methods } \\
\text { used for zirconia was on par with the laboratory } \\
\text { alternative tested. }\end{array}$ \\
\hline
\end{tabular}


Table 2

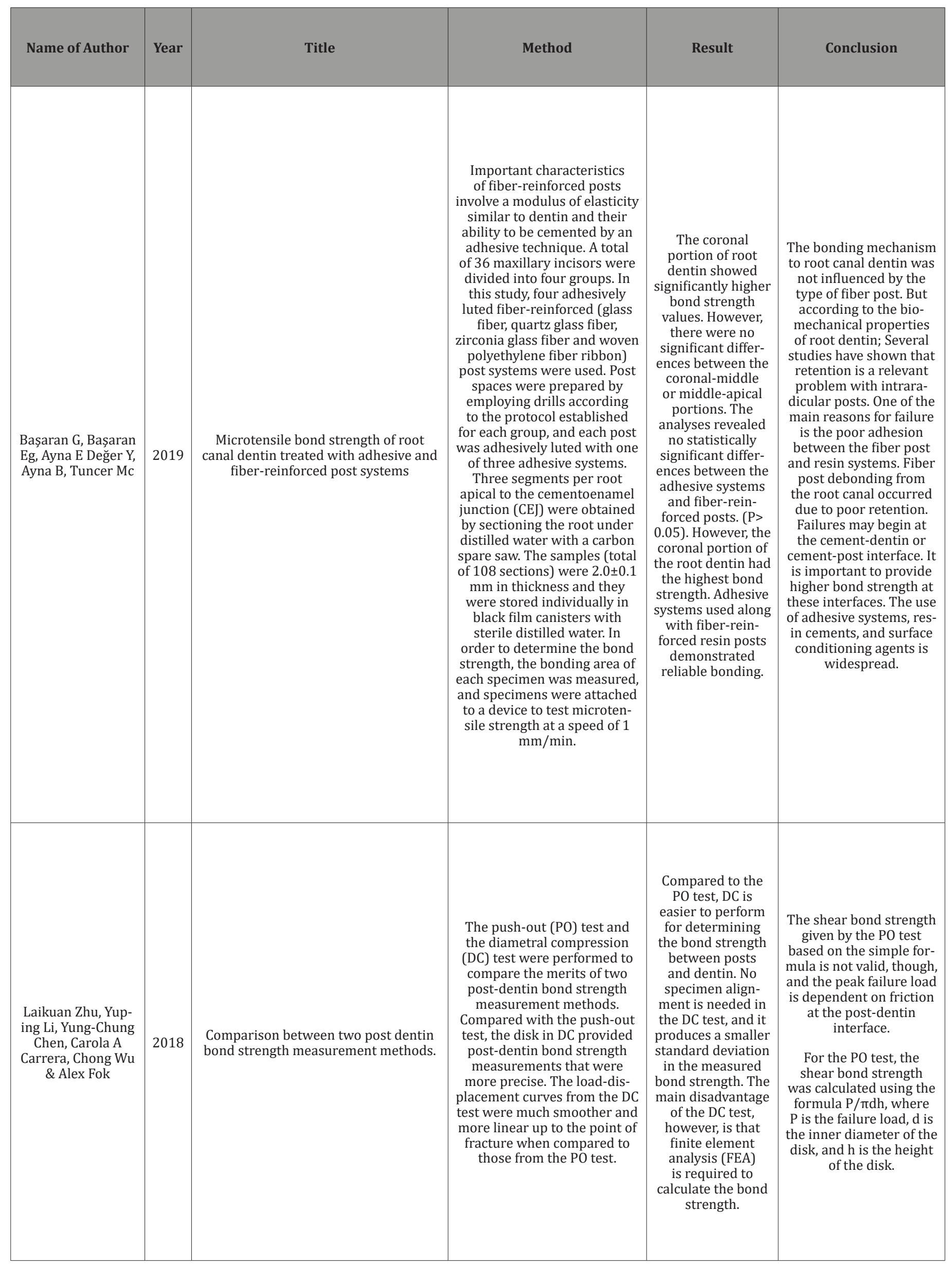




\begin{tabular}{|c|c|c|c|c|c|}
\hline $\begin{array}{l}\text { Khoroushi M,Feiz } \\
\text { A, Khodamoradi R }\end{array}$ & 2010 & $\begin{array}{l}\text { Fracture Resistance of Endodontical- } \\
\text { ly-treated Teeth: Effect of Combination } \\
\text { Bleaching and an Antioxidant }\end{array}$ & $\begin{array}{l}\text { This in vitro study assessed } \\
\text { the fracture resistance of } \\
\text { endodontically-treated teeth } \\
\text { undergoing combination } \\
\text { bleaching with } 38 \% \text { and } 9.5 \% \\
\text { hydrogen peroxide gels as } \\
\text { in-office and at-home bleach- } \\
\text { ing techniques, respectively. } \\
\text { In addition, the effect of an } \\
\text { antioxidizing agent, sodium } \\
\text { ascorbate, was investigated. } \\
\text { Methods and Materials: Sixty } \\
\text { maxillary premolars were } \\
\text { endodontically-treated, re- } \\
\text { ceived a glass ionomer barrier } \\
\text { as a mechanical seal and were } \\
\text { embedded in acrylic resin up } \\
\text { to the cemento-enamel junc- } \\
\text { tion. The specimens were di- } \\
\text { vided into four groups (n=15) } \\
\text { as follows: G I: no bleaching, } \\
\text { access cavity restored with } \\
\text { resin composite (negative } \\
\text { control); G II: bleached for } \\
\text { three weeks dily using 9.5\% } \\
\text { hydrogen peroxide for two } \\
\text { hours and three sessions of } \\
\text { in-office bleaching using } 38 \% \\
\text { hydrogen peroxide every } \\
\text { seven days, then restored } \\
\text { (positive control); G III: } \\
\text { bleached similar to G II and } \\
\text { restored after one week; G IV: } \\
\text { bleached similar to G II, along } \\
\text { with the use of an antioxidiz- } \\
\text { ing agent for } 24 \text { hours, then } \\
\text { restored. In each in-office and } \\
\text { athome bleaching session, the } \\
\text { whitening gels were applied } \\
\text { to the buccal surface of the } \\
\text { tooth and placed inside the } \\
\text { pulp chamber (inside/outside } \\
\text { bleaching technique). Finally, } \\
\text { the specimens underwent } \\
\text { fracture resistance testing; } \\
\text { the data were analyzed using } \\
\text { ANOVA and Scheffés test } \\
\text { ( } \alpha=0.05 \text { ). }\end{array}$ & $\begin{array}{c}\text { Significant } \\
\text { differences were } \\
\text { observed among } \\
\text { the study groups } \\
\text { (p0.05). }\end{array}$ & $\begin{array}{l}\text { Within the limitations } \\
\text { of the current study, it } \\
\text { can be concluded that } \\
\text { the fracture resistance of } \\
\text { endodontically-treated } \\
\text { teeth decreases after } \\
\text { combination bleach- } \\
\text { ing. The use of sodium } \\
\text { ascorbate can reverse } \\
\text { decreased fracture } \\
\text { resistance }\end{array}$ \\
\hline $\begin{array}{l}\text { Reza Talebian, Zah- } \\
\text { ra Khamver- } \\
\text { di,1 Maryam } \\
\text { Nouri,2 and Shahin } \\
\text { Kasraei; }\end{array}$ & 2014 & $\begin{array}{l}\text { Effect of ascorbic acid on bond strength } \\
\text { between the hydrogen peroxide-treated } \\
\text { fiber posts and composite resin }\end{array}$ & $\begin{array}{l}\text { effect of } 10 \% \text { ascorbic acid on } \\
\text { the bond strength between } \\
\text { fiber post and composite } \\
\text { resin core after applying } 24 \% \\
\text { hydrogen peroxide. Materials } \\
\text { and Methods: } \\
\text { Twenty-four hydrogen } \\
\text { peroxide-treated fiber posts } \\
\text { were divided into } 4 \text { groups ( } \\
\text { = 6). Group } 1 \text { was the control } \\
\text { group with no treatment. } \\
\text { In groups } 2-4, \text { post surfaces } \\
\text { were treated with } 10 \% \text { v } \\
\text { ascorbic acid solution for } 10 \text {, } \\
30 \text { and } 60 \text { minutes, respec- } \\
\text { tively. Cores were built up } \\
\text { using flowable composite } \\
\text { resin. Two sticks were pre- } \\
\text { pared from each specimen. } \\
\text { Microtensile bond strength } \\
\text { test was performed for each } \\
\text { stick. Failure modes of sticks } \\
\text { were evaluated under a ste- } \\
\text { reomicroscope }(\times 20) \text {. Surface } \\
\text { morphologies of two frac- } \\
\text { tured sticks from each group } \\
\text { were assessed by SEM. }\end{array}$ & $\begin{array}{l}\text { Data were ana- } \\
\text { lyzed using one- } \\
\text { way ANOVA and } \\
\text { Tukey HSD tests ( } \alpha \\
=0.05) \text {.The highest } \\
\text { microtensile bond } \\
\text { strength was } \\
\text { observed in Group } \\
4(20.55 \pm 2.09) \\
\text { and the lowest in } \\
\text { Group } 1(10.10 \\
\pm 0.55) \text {. There } \\
\text { were significant } \\
\text { differences in } \\
\text { microtensile bond } \\
\text { strength between } \\
\text { all the groups }(\mathrm{P}< \\
0.05) .\end{array}$ & $\begin{array}{l}\text { It is concluded that } \\
\text { ascorbic acid application } \\
\text { increased the microten- } \\
\text { sile bond strength } \\
\text { between the hydrogen } \\
\text { peroxide treated fiber } \\
\text { post and composite } \\
\text { resin core. The increase } \\
\text { is dependent on the } \\
\text { duration of exposure to } \\
\text { the antioxidant. }\end{array}$ \\
\hline
\end{tabular}




\begin{tabular}{|c|c|c|c|c|c|}
\hline $\begin{array}{l}\text { Nihan Gonulolay, } \\
\text { Elif Kalyoncuo glu, } \\
\text { Ertan Erta }\end{array}$ & 2015 & $\begin{array}{l}\text { Effect of sodium ascorbate on dentin } \\
\text { bond strength after treatment with } \\
\text { oxidizing root canal irrigants. }\end{array}$ & $\begin{array}{l}\text { The aim of this study was to } \\
\text { evaluate the effect of } 10 \% \\
\text { sodium ascorbate solution } \\
\text { on dentin bond strength after } \\
\text { being treated with differ- } \\
\text { ent oxygenreleasing root } \\
\text { canal irrigants. Materials and } \\
\text { methods: Twenty-one human } \\
\text { third molars were used in this } \\
\text { study. The specimens were } \\
\text { randomly divided into seven } \\
\text { groups according to irrigation } \\
\text { solutions, as follows: Group C } \\
\text { (control group), distilled wa- } \\
\text { ter; Group SH, 5.25\% sodium } \\
\text { hypochlorite (NaOCl); Group } \\
\text { SHA, 5.25\% NaOCl p 10\% } \\
\text { sodium ascorbate solution; } \\
\text { Group HP, 10\% hydrogen } \\
\text { peroxide (H2O2); Group HPA, } \\
10 \% \text { H2O2 p 10\% sodium } \\
\text { ascorbate solution; and Group } \\
\text { OW, ozonated water; Group } \\
\text { OWA, ozonated water p 10\% } \\
\text { sodium ascorbate solution. } \\
\text { A two-step self-etching } \\
\text { adhesive system (CLEARFIL } \\
\text { SE Bond) was applied to } \\
\text { the surfaces, and resin core } \\
\text { buildups (Filtek Z550) were } \\
\text { placed. specimens were } \\
\text { sectioned into 1-mm2 beams } \\
\text { and tested in a microtensile } \\
\text { bondstrength (mTBS) testing } \\
\text { machine at a crosshead speed } \\
\text { of } 1 \text { mm/minute. Fractured } \\
\text { specimens were examined } \\
\text { with a stereomicroscope } \\
\text { to determine the mode of } \\
\text { failure (adhesive, cohesive, or } \\
\text { mixed). }\end{array}$ & $\begin{array}{l}\text { The data were an- } \\
\text { alyzed by one-way } \\
\text { analysis of vari- } \\
\text { ance and Tukey } \\
\text { tests }(\mathrm{P}<0.05) \text {. } \\
\text { Results: The ozo- } \\
\text { natedwater-treat- } \\
\text { ed groups showed } \\
\text { the lowest mTBS } \\
\text { values among all } \\
\text { the groups. }\end{array}$ & $\begin{array}{c}\text { Although the } 10 \% \\
\text { sodium ascorbate appli- } \\
\text { cation increased dentin } \\
\text { bond strength in Group } \\
\text { OW, the difference was } \\
\text { not significant }(P>0.05) \\
\text { With ozonated water } \\
\text { only as irrigant. }\end{array}$ \\
\hline
\end{tabular}

Table 3: Characteristics of zirconia after surface treatment (Mean \pm $\mathrm{SD})$.

\begin{tabular}{|c|c|}
\hline Surface Treatment & Mean BS.SD \\
\hline HFP & $8.88 \pm 5.15$ \\
\hline APP & $11.69 \pm 5.97$ \\
\hline HFNPP & $13.26 \pm 5.75$ \\
\hline Laser treatment & $7.502 \pm 5.23$ \\
\hline
\end{tabular}

Table 4: Means and standard Deviations for Shear Bond Strength Results (MPa) According to the Different Surface Treatment and Multilink Speed Cement.

\begin{tabular}{|c|c|c|}
\hline \multirow{2}{*}{$\begin{array}{c}\text { Priming Condi- } \\
\text { tions }\end{array}$} & \multicolumn{2}{|c|}{ Surface Conditions } \\
\cline { 2 - 3 } & $\begin{array}{c}\text { No Air-Abrasion(pol- } \\
\text { ished) }\end{array}$ & Air-Abrasion \\
\hline None & $3.91(0.72) \mathrm{A}$ & $10.56(3.32) \mathrm{B}$ \\
\hline Monoband-Plus & $4.86(1.77) \mathrm{A}$ & $8.93(3.13) \mathrm{B}$ \\
\hline Z-Prime plus & $8.27(2.79) \mathrm{B}$ & $16.50(2.26) \mathrm{C}$ \\
\hline Cojet and ESPE Sil & $8.54(3.98) \mathrm{B}$ & \\
\hline
\end{tabular}

\section{Discussion}

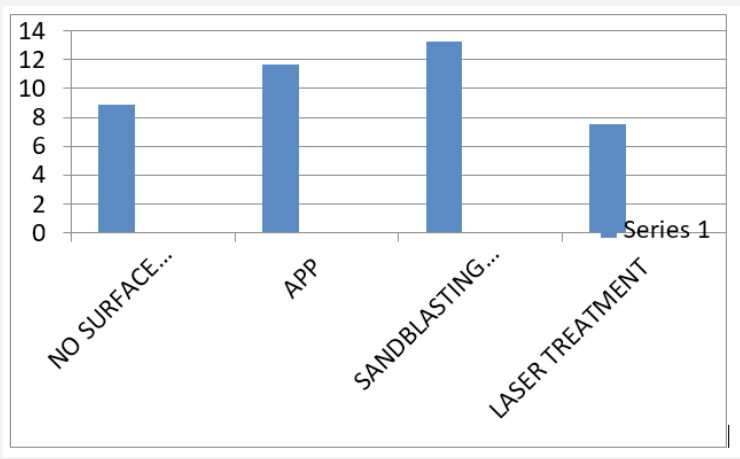

Figure 2: Showed highest surface treatment in sandblasting following by air-borne particles app then lowest by laser treatment where cracks also found. 


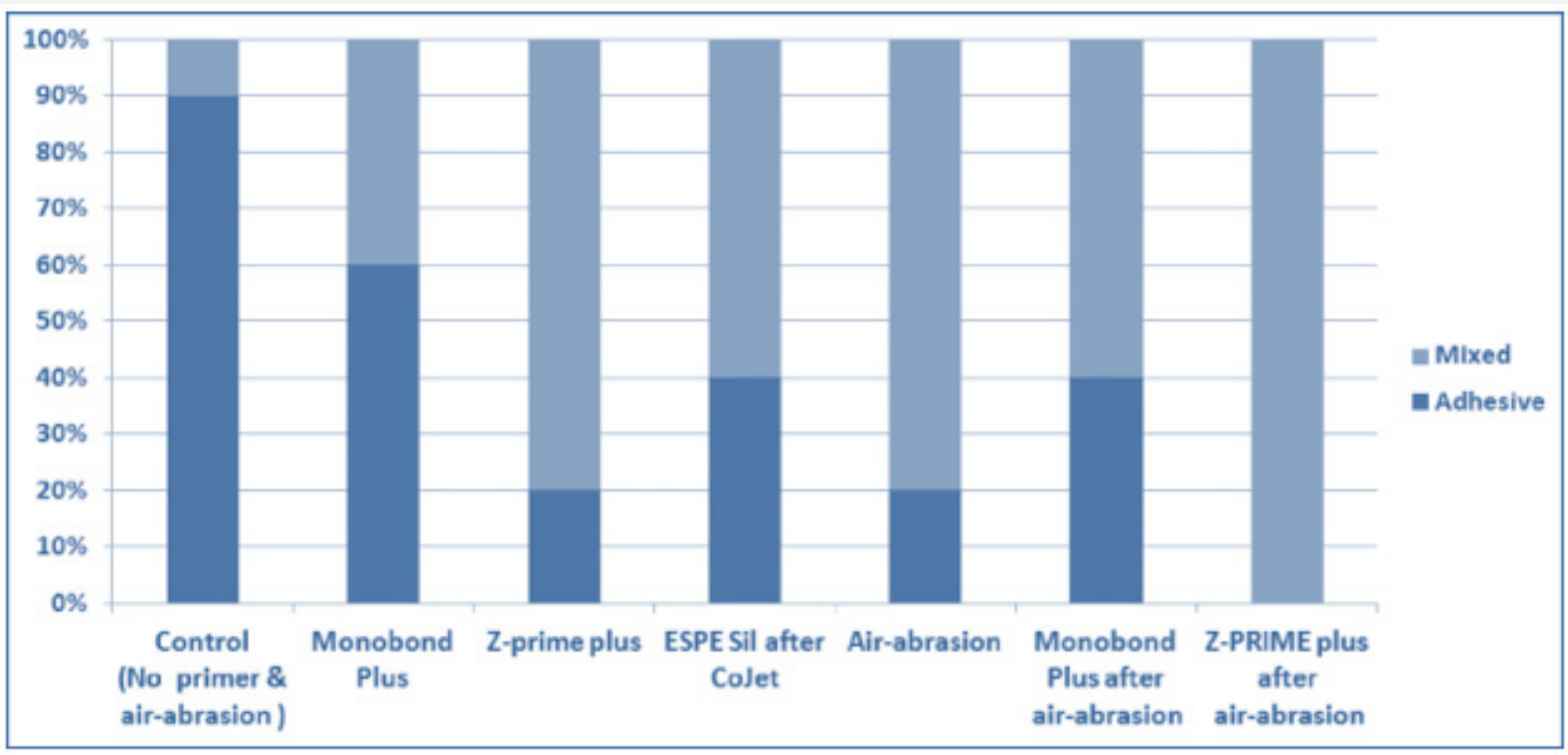

Figure 3: Bond Strength Between Y-TZP Ceramic and Resin Cement.

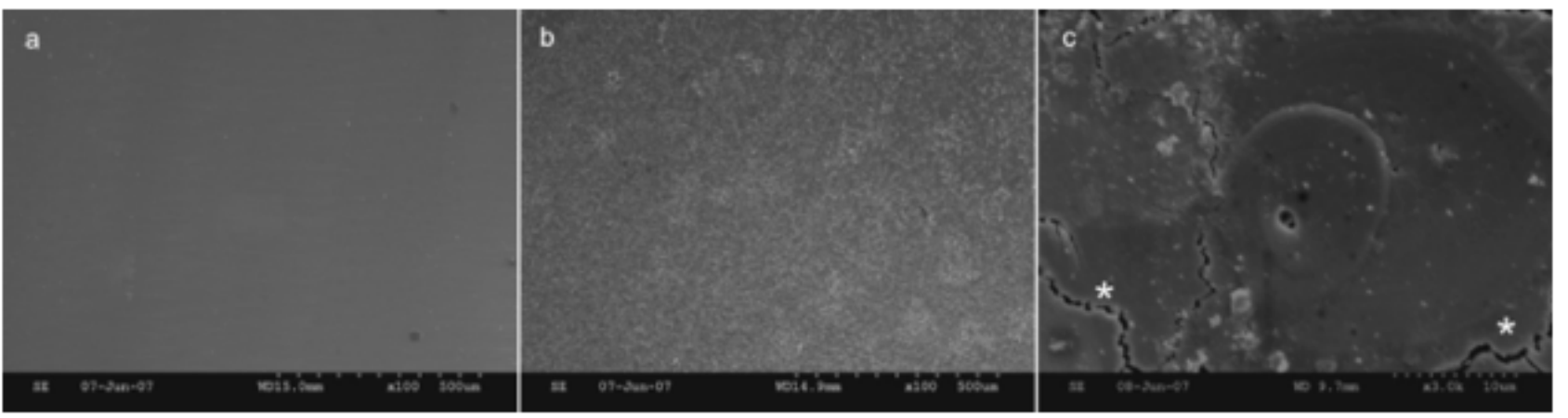

Figure 4:a) Y-TZP surface untreated.

b) Y-TZP surface treated air abrasion with $53 \mu \mathrm{m}$ Al2O3 particles.

c) Y-TZP surface irradiated with the Er: YAG laser.

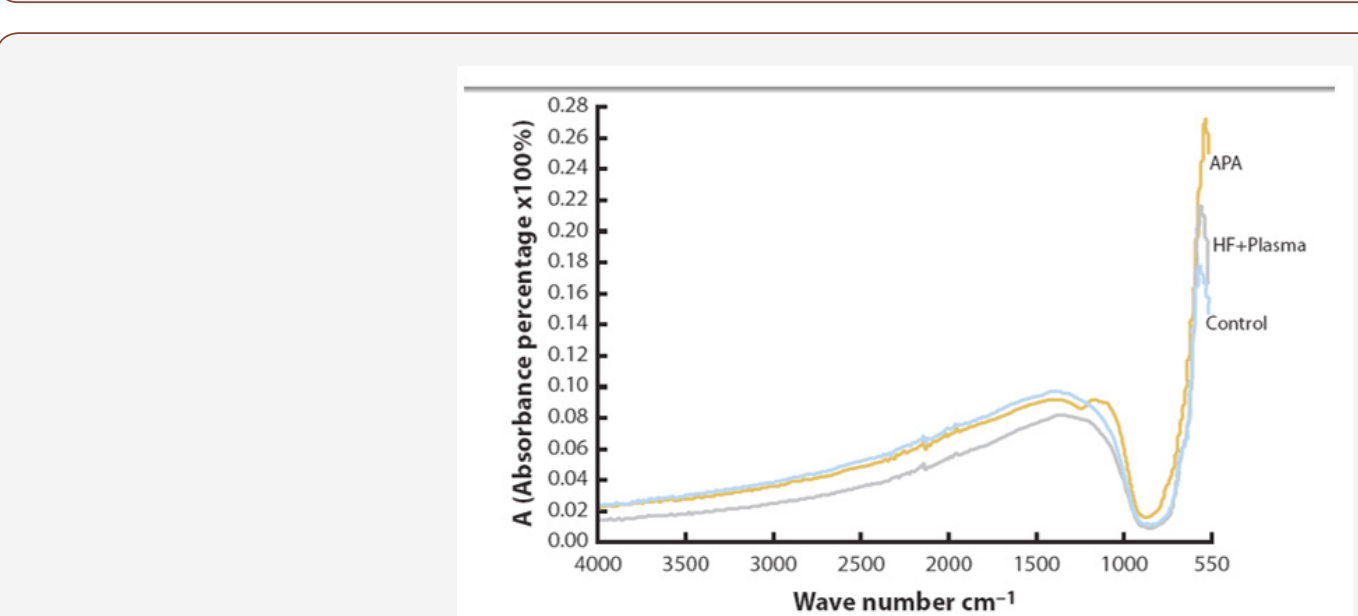

Figure 5: Fourier transform infrared spectrometer analysis. Similar absorbance peaks for zirconia surface after sandblasting and after hydrofluoric plus plasma application. APA, airborne particle abrasion; HF, 10\% hydrofluoric acid. 


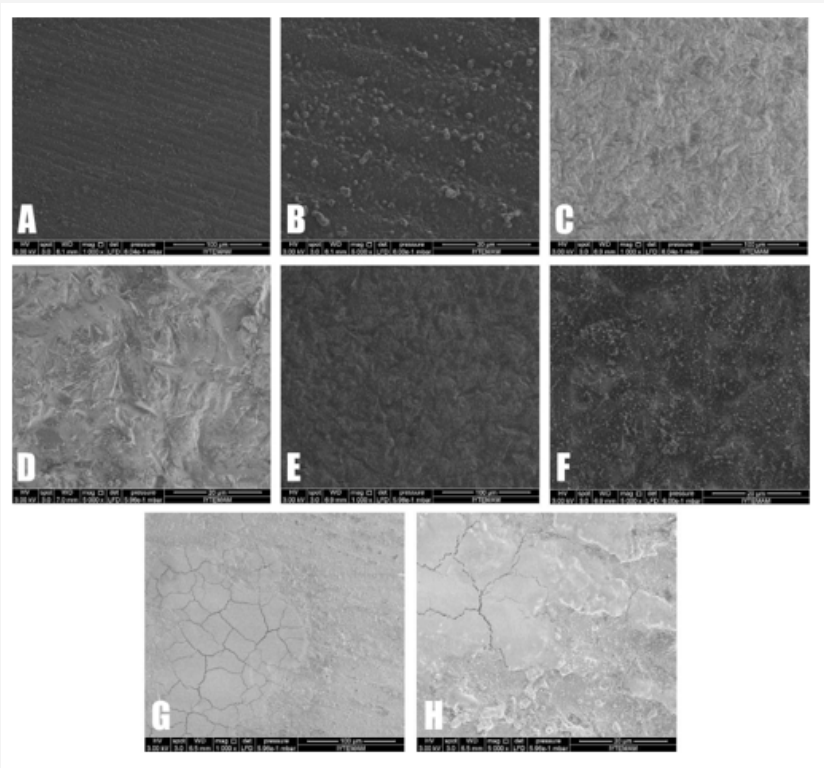

Figure 6: $(A$ and $B)$ no surface treatment.

(C and D): Airborne particle abraded.

( $\mathrm{E}$ and $\mathrm{F})$ : Tribochemical silica coated.

( $\mathrm{G}$ and $\mathrm{H})$ : Laser applied.

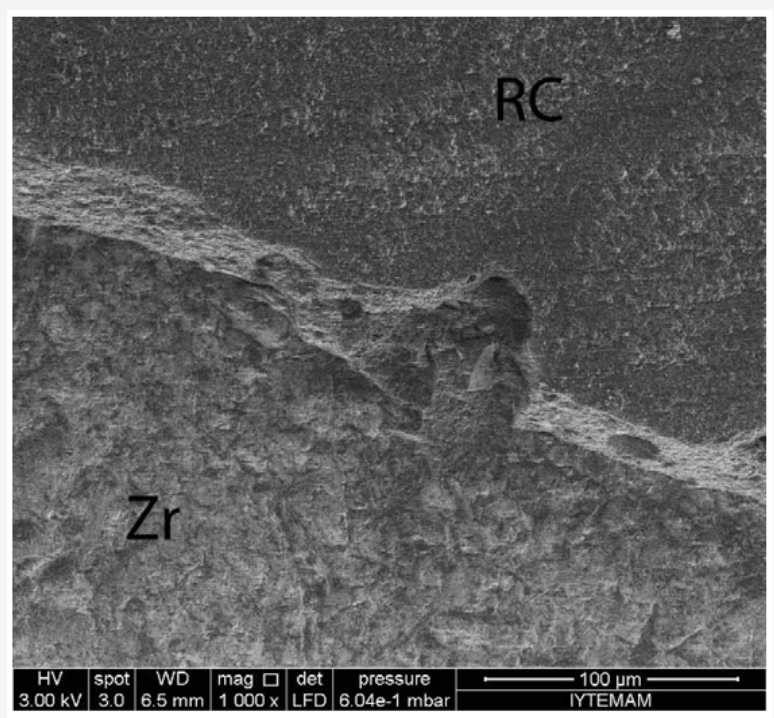

Figure 7: SEM photograph. (10003 original magnification) of APA treated/Rely X U100 adhesive cement failed surface (RC, resin cement; Zr, zirconia).

According to the analysis of the selected papers it could be seen that the use of $\mathrm{Al}_{2} \mathrm{O}_{3}$ air-abrasion followed by application of phosphate monomers-based primers or resin cement tends to produce more reliable results. Several surface treatment methods have been proposed to overcome intrinsic acid resistance of $\mathrm{ZrO}_{2}$; however, these methods have presented controversial results about their effectiveness on bond strength improvement. Nonetheless it seems important to select multifunctional methods, which mix the ability to create a rough surface for micromechanical interlocking and increase the surface area to establish chemical bond with reactive substances.
Yang et al. [9], agreed and stated that a reliable bond strength after air-abrasion at 2.5 bars or the combination of low-pressure air-abrasion and priming with MDP-containing primers. Proper restoration of endodontically treated teeth begins with a good understanding of their physical and biomechanical properties, restorative and occlusal principles. Although many new restorative materials have become available over the past several years, some basic concepts in restoring endodontically treated teeth remain the same. One of the main concerns in this systematic review is the Bonding in Endodontically Treated Teeth and how affect in bond strength to zirconia restoration. Reduced bond strength 
after endodontic treatment demonstrated clinically by debonding of zirconia restoration and showed to increase the bond strength and this may be due to reverse the oxidative effect on dentin this is agreed with Başaran G et al. [31], Laikuan Z et al. [32], Khoroushi $\mathrm{M}$ [34]. Who stated that the antioxidant ability of sodium ascorbate helps neutralize and reverse the oxidizing effects of the $\mathrm{NaOCl}$. And Nihan Gonulol ay, et al. [35] who stated that 10\% sodium ascorbate for one minute restores the original bond strengths allows free-radical polymerization of the adhesive to proceed without premature termination, reversing the compromised bond strength could be very effective in modifying dentin surface and hence affecting its bond strength to other materials Therefore they could also increase the resistance of dentin to biodegradation and hence stabilize the resin adhesive-dentin interface by attacking any residual bacteria or inhibiting the degradation of the hybrid layer.

\section{Conclusion}

Within the limitation of this systematic review it can be concluded that: Sodium ascorbate may restore strengths allow free adhesive to precede, reversing the change in dentin surface and consequently increase bond strength. The changed dentin will resist bacterial biodegradation.

\section{Acknowledgement}

None.

\section{Conflict of Interest}

No conflict of interest.

\section{References}

1. Leprince JG, Leloup G, Hardy CM (2017) Considerations for the Restoration of Endodontically Treated Molars. In the Guidebook to Molar Endodontics: 169-205.

2. Gulabivala K, Patel B, Evans G, Yuan Ling Ng (2005) Effects of mechanical and chemical procedures on root canal surfaces. Endodontic Topics 10(1): 103-122.

3. Prasanna KB, Jayasheelan N, Shetty HK, Shetty V, Sreegowri (2018) Considerations in restoring an endodontically treated teeth- A Review. International Journal of Advanced Research 6(8): 874-877.

4. Hamdy A (2015) Effect of Full Coverage, Endocrowns, Onlays, Inlays Restorations on Fracture Resistance of Endodontically Treated Molars. J Dent Oral Health 1(5): 10-23.

5. Vellez P, Eliana, Cardona S, Maria A (2014) Characterization of endodontically treated dentin. Journal of the Faculty of Dentistry University of Antioquia 25(2): 372-388.

6. Saha SG, Sharma V, Bharadwaj A, Shrivastava P, Saha MK, et al. (2017) Effectiveness of Various Endodontic Irrigants on the Micro-Hardness of the Root Canal Dentin: An in vitro Study. J Clin Diagn Res 11(4): ZC01ZC04.

7. Mathur R, Sharma M, Sharma D, Raisingani D, Vishnoi S, et al. (2015) Evaluation of Coronal Leakage Following Different Obturation Techniques and in-vitro Evalution Using Methylene Blue Dye Preparation. J Clin Diagn Res 9(12): ZC13-ZC17.

8. Tsuo Y, Yoshida K, Atsuta M (2006) Effects of alumina-blasting and adhesive primers on bonding between resin luting agent and zirconia ceramics. Dent Mater J 25(4): 669-674.

9. Yang B, Barloi A, Kern M (2010) Influence of air-abrasion on zirconia ceramic bonding using an adhesive composite resin. Dent Mater 26(1): 44-50.

10. Yun JY, Ha SR, Lee JB, Kim SH (2010) Effect of sandblasting and various metal primers on the shear bond strength of resin cement to Y-TZP ceramic. Dent Mater 26(7): 650-658.

11. Magnes P, Paranhos MP, Burnett LH (2010) New zirconia primer improves bond strength of resin-based cements. Dent Mater 26(4): 345352.

12. Kern M, Barloi A, Yang B (2009) Surface conditioning influences zirconia ceramic bonding. J Dent Res 88(9): 817-822

13. Abuhaimed TS, Abou Neel EA (2017) Sodium hypochlorite irrigation and its effect on bond strength to dentin. Biomed Res Int.

14. Wolfart M, Lehmann F, Wolfart S, Kern M (2007) Durability of the resin bond strength to zirconia ceramic after using different surface conditioning methods. Dent Mater 23(1): 45-50.

15. Uo M, Sjögren G, Sundh A, Goto M, Watari F, et al. (2006) Effect of surface condition of dental zirconia ceramic (Denzir) on bonding. Dental Mater j 25(3): 626-631.

16. Nothdurft FP, Motter PJ, Pospiech PR (2009) Effect of surface treatment on the initial bond strength of different luting cements to zirconium oxide ceramic. Clin Oral Investig 13(2): 229-235.

17. Kim MJ, Kim YK, Kim KH, Kwon TY (2011) Shear bond strengths of various luting cements to zirconia ceramic: surface chemical aspects. J Dent 39(11): 795-803.

18. Blatz MB, Phark JH, Ozer F, Mante FK, Saleh N, et al. (2010) In vitro comparative bond strength of contemporary self-adhesive resin cements to zirconium oxide ceramic with and without air-particle abrasion. Clin Oral Investig 14(2): 187-192.

19. Saleh NE, Guven MC, Yildirim G, Erol F (2019) Effect of different surface treatments and ceramic primers on shear bond strength of self-adhesive resin cement to zirconia ceramic. Niger J Clin Pract 22(3): 335.

20. Aboushelib MN, Feilzer AJ, Kleverlaan CJ (2010) Bonding to zirconia using a new surface treatment. Journal of Prosthodontics: Implant. Esthetic and Reconstructive Dentistry 19(5): 340-346.

21. Faria AC, Rodrigues RC, De Almeida Antunes RP, De Mattos, Ribeiro RF (2011) Endodontically treated teeth: characteristics and considerations to restore them. J Prosthodont Res 55(2): 69-74.

22. Turp JC, Heydecke G, Krastl G, Pontius O, Antes G, et al. (2007) Restoring the fractured root-canal-treated maxillary lateral incisor: in search of an evidence-based approach. Quintessence Int 38(3): 179-191.

23. Nihan Gonulol, Elif Kalyoncuoglu (2000) Ertan Ertas Effect of sodium ascorbate on dentin bond strength after treatment with oxidizing root canal irrigantsy. Journal of Dental Science.

24. Gönülol N, Kalyoncuoğlu E, Ertaș E (2015) Effect of sodium ascorbate on dentin bond strength after treatment with oxidizing root canal irrigants. Journal of Dental Sciences, 10(2): 139-144.

25. Kimyai S, Valizadeh H (2008) Comparison of the effect of hydrogel and a solution of sodium ascorbate on dentin-composite bond strength after bleaching. J Contemp Dent Pract 9(2): 105-112.

26. Dimitriu B, Vârlan C, Suciu I, Vârlan V, Bodnar D (2009) Current considerations concerning endodontically treated teeth: alteration of hard dental tissues and biomechanical properties following endodontic therapy. J Med Life 2(1): 60-65.

27. Bravo C, Sampaio CS, Hirata R, Rontani RM, Mayoral JR, et al. (2017) Effect of $2 \%$ chlorhexidine on dentin shear bond strength of different adhesive systems: A 6 months evaluation. Int J Morphology 35(3): 11401146. 
28. Gomes BP, Ferraz CC, Vianna ME, Berber VB, Teixeira FB, et al. (2001) In vitro antimicrobial activity of several concentrations of sodium hypochlorite and chlorhexidine gluconate in the elimination of Enterococcus faecalis. Int Endod J 34(6): 424-428.

29. Zamany A, Safavi K, Spångberg LS (2003) The effect of chlorhexidine as an endodontic disinfectant. Oral Surg Oral Med Oral Pathol Oral Radiol Endod 96(5): 578-581.

30. Abdullah OA, YU Xudong, Pollington S, Muhammed FK, Liu YI (2019) Effects of different surface treatments on the shear bond strength of veneering ceramic materials to zircon. J Adv Prosthodont 11(1): 65-74.

31. Başaran G, Başaran Eg, Ayna E, Değer Y, Ayna B, Tuncer Mc (2019) Microtensile bond strength of root canal dentin treated with adhesive and fiber-reinforced post systems Braz. Oral Res 33: e0271.
32. Laikuan Zhu, Yuping Li, Yung Chung Chen, Carola A Carrera, Chong $\mathrm{Wu}$, et al. (2018) Comparison between two post dentin bond strength measurement methods. Nature 8: 2350.

33. Khoroushi M, Feiz A, Khodamoradi R (2010) Fracture Resistance of Endodontically-treated Teeth: Effect of Combination Bleaching and an Antioxidant. Oper Dent 35(5): 530-537.

34. Reza Talebian, Zahra Khamverdi, Maryam Nouri, Shahin Kasraei (2014) Effect of ascorbic acid on bond strength between the hydrogen peroxidetreated fiber posts and composite resin cores. J Conserv Dent 17(3): $220-224$.

35. Nihan Gonulol ay, Elif Kalyoncuo glu, Ertan Ertas (2015) Effect of sodium ascorbate on dentin bond strength after treatment with oxidizing root canal irrigants. Journal of Dental Science 10: 139-144. 